\title{
VITALITAS SEKUJANG DI KABUPATEN SELUMA
}

\section{SEKUJANG'S VITALITY IN SELUMA DISTRICT}

\author{
Sarwo F. Wibowo \\ Kantor Bahasa Bengkulu \\ sarwoferdiwibowo.sfw@gmail.com
}

\begin{abstract}
ABSTRAK
Penelitian sebelumnya yang menyimpulkan sekujang berada di ambang kepunahan tidak didasarkan pada suatu indikator. Penelitian ini bertujuan memperbaiki hal tersebut dengan menggunakan indikator vitalitas bahasa yang dimodifikasi untuk mengukur vitalitas sastra. Cara yang sama pernah dilakukan oleh Pusat Perlindungan Badan Bahasa pada tahun 2017. Metode yang digunakan adalah metode campur (mix method) melalui pengumpulan data kuantitatif dari kuesioner yang diperdalam dengan pengumpulan data kuantitatif melalui metode wawancara. Hasil penelitian menunjukkan bahwa sekujang saat ini tergolong sebagai sastra lisan yang mengalami kemunduran dengan skor 0,42 dengan penyebab utama 1) tidak cukup adaptif untuk dialihwahanakan, 2) tidak terintegrasinya sekujang dalam kurikulum muatan lokal, dan 3) kemampatan transmisi antargenerasi. Refleksi terhadap penelitian ini menunjukkan kelemahan teoritis pada asumsi dasar penelitian dengan menggunakan indikator vitalitas bahasa yaitu; 1) kepunahan bahasa tidak selalu disertai kepunahan sastra lisan; 2) tidak mungkin menentukan patokan keaslian suatu sastra lisan karena dalam transmisinya selalu mengalami proses reproduksi dan rekreasi.
\end{abstract}

Kata kunci: Sekujang, vitalitas sastra, sastra lisan, Kabupaten Seluma

\section{ABSTRACT}

Previous research resume Sekujang almost vanish not based on suitable indicators. This research aim to make previous finding more measurable by using modified language vitality indicators to measure folklore vitality. The same way applied by Pusat Perlindungan Badan Bahasa in 2017. This research used mix method through questionnaire to collect quantitative data and interview to elaborate collected quantitative data. Result shows Sekujang nowadays categorized as eroding folklore (total score 0,42) with main threaten factors 1) not adaptive to ecranitation, 2) unintegrated to local content curriculum, 3) occlusion of intergeneration transmission. The reflection of this research exposed theoretical laxity on basic assumption by using language vitality indicators that is 1) language death not always followed by folklore; 2) quite impossible to determine folklore authenticity benchmark because always reproduce and recreate in it transmission process.

Keywords: Sekujang, folklore vitality, folklore, literature vitality 


\section{PENDAHULUAN}

Penelitian eksploratif terhadap Sekujang menunjukkan bahwa tradisi lisan ini diambang kepunahannya. Wibowo (2014:40) menyebut bahwa setidaknya dari tujuh desa yang diketahui melaksanakan tradisi sekujang setiap tahunnya (Tapak Gedung dan Talang Karet di kabupaten Kepahiang dan Talang Benuang, Talang Alai, Simpang Tiga Sukaraja, hingga ke Sengkuang di Kabupaten Seluma), hanya tingga di desa Talang Benuang saja pelaksanaan tradisi ini dapat ditemukan. Lebih lanjut ditemukan bahwa kepunahan tersebut terutama disebabkan oleh tidak adanya pewaris dari tetuo Sekujang atau dapat dikatakan transmisi tradisi ini ke generasi selanjutnya mengalami kemampatan.

Sebagai sebuah penelitian yang bersifat eksploratif, penelitian di atas tentu memiliki berbagai kekurangan di samping peran besarnya dalam mendokumentasikan Sekujang. Namun sebagai konsekuensi logis dari metode eksploratif, penelitian tersebut memiliki cakupan yang amat luas sehingga tidak terlalu memiliki fokus yang jelas. Berdasarkan hal tersebut, klaim kajian tersebut dapat diragukan setidaknya atas dua pertimbangan yaitu 1) kesimpulan tersebut disimpulkan hanya berdasarkan informasi dari masyarakat satu desa Talang Benuang yang menjadi daerah penelitian utama, 2) penelitian tersebut tidak menggunakan indikator yang jelas untuk mengukur vitalitas tradisi lisan Sekujang.

Dalam perspektif vitalitas, penelitian tersebut meski menyebut mengenai masalah pewarisan tidak terlalu fokus pada transmisi yang menjadi faktor penting dalam keberlangsungan suatu tradisi lisan. Di samping itu, informasi mengenai desa-desa lain di Kabupaten Seluma yang masih menyelenggarakan tradisi ini perlu ditelusuri lebih jauh untuk memastikan kelangsungan tradisi ini secara lebih faktual, sehingga klaim bahwa hanya tinggal satu desa yang menyelenggarakan tradisi ini bisa diperiksa ulang. Harus diakui bahwa untuk menentukan vitalitas Sekujang secara lebih terukur perlu dilakukan penelitian baru yang lebih fokus pada aspek-aspek yang mempengaruhi keberlangsungan sastra lisan ini.

Meski tidak ada teori yang secara khusus dapat diterapkan untuk mengukur vitalitas suatu karya sastra, ada beberapa penelitian yang dapat dirujuk sebagai contoh bagi penentuan status vitalitas suatu sastra lisan. Badan Bahasa (2017:12) mendasarkan vitalitas suatu sastra lisan pada asumsi bahwa keberlangsungan bahasa menjadi faktor utama keberlangsungan sastra karena merupakan medium bagi sastra tersebut. Oleh karena itu Badan Bahasa menggunakan indikator vitalitas bahasa sebagai indikator pengukur vitalitas sastra. Sementara itu Asosiasi Tradisi Lisan (ATL) menekankan pada aspek transmisi tradisi lisan yang membutuhkan pendekatan yang lebih bersifat etnografik.

Metode-metode tersebut memiliki kelebihan dan kekurangan masingmasing. ATL misalnya membutuhkan keterlibatan yang lama dengan masyarakat objek penelitian, sehingga dapat dikatakan bahwa kurang aplikatif dalam jangka waktu yang terbatas. Selain itu masalah vitalitas hanya menjadi bagian dari keseluruhan penelitian mengenai sastra lisan. Sementara, penelitian dengan pola Badan Bahasa menghasilkan data yang agak kering karena cenderung pada penyajian data kuantitatif meski menggunakan metode campuran (mix method). Kedua kelemahan dalam penelitian yang telah dilakukan sebelumnya tersebut akan diatasi dalam penelitian ini melalui beberapa hal seperti 1) menggunakan 
indikator vitalitas bahasa karena indikator vitalitas bahasa memungkinkan pengungkapan yang lebih komprehensif tentang vitalitas suatu sastra lisan, 2) melakukan penekanan-penekanan tertentu dalam vitalitas sastra khususnya pada faktor transmisi, sikap terhadap sastra lisan, daya tanggap terhadap media, dan kebijakan pemerintah, 3) pemilihan daerah pengamatan yang lebih terjangkau sehingga pemanfaatan waktu dapat dimaksimalkan untuk menjaring data kualitatif di lapangan.

Hasil penelitian ini dapat memberikan gambaran yang lebih fokus dan sistematis mengenai faktor-faktor penyebab kepunahan tradisi lisan sekujang. Penelitian ini memiliki peran penting sebagai dasar dalam menentukan strategi pelestarian tradisi lisan Sekujang yang lebih terarah. Berangkat dari penelitian ini, pada tahun sleanjutnya akan dirumuskan skema yang akan diujicobakan dalam usaha pelestarian sastra lisan tersebut. Berdasarkan penjabaran di atas, masalah yang akan dijawab pada penelitian ini adalah: Bagaimana vitalitas tradisi lisan sekujang di Kabupaten Seluma berdasarkan teori yang didasarkan pada vitalitas bahasa dan pola transmisinya?

Teori vitalitas bahasa akan digunakan teori bantu dalam menjawab pertanyaan di atas. Hal ini didasarkan pada asumsi bahwa sastra lisan dan bahasa terkait sangat erat sehingga tradisi lisan tidak mungkin bertahan tanpa lestarinya bahasa yang menjadi mediumnya. Teori vitalitas bahasa dipilih karena menyediakan kriteria yang relevan untuk menjadi indikator vitalitas suatu tradisi lisan, selain karena Badan Bahasa sebagai induk instansi Kantor Bahasa menggunakan teori yang sama.

Keputusan ini memiliki landasan yang kuat karena dalam teori budaya bahasa merupakan unsur yang tak larut (Gunarwan, 2018: 118). Bahasa juga menjadi medium utama, dalam beberapa kasus bahkan satu-satunya, bagi sastra lisan. Oleh karena itu keberlangsungan suatu bahasa berdampak sangat besar pada kelangsungan sastra. Relasi sistemik antara bahasa dan sastra ini yang memungkinkan penggunaan indikator vitalitas bahasa sebagai indikator bagi vitalitas sastra. Indikator vitalitas bahasa yang paling lengkap dan paling mutakhir telah dirumuskan oleh UNESCO dalam dokumen languange vitality and endangerment. Menurut UNESCO (2003) vitalitas suatu bahasa juga dapat ditentukan berdasarkan sembilan faktor berikut.

1) Transmisi bahasa antargenerasi

2) Jumlah penutur yang besar

3) Perbandingan penutur dengan jumlah penduduk

4) Kecenderungan dalam ranah pemakaian bahasa

5) Daya tanggap terhadap ranah baru dan media

6) Materi untuk pendidikan bahasa dan keberaksaraan

7) Kebijakan bahasa oleh pemerintah dan institusi, termasuk status resmi dan pemakaiannya

8) Sikap komunitas penutur terhadap bahasa mereka

9) Jumlah dan kualitas dokumentasi bahasa

Konsekuensi logis dari perubahan objek vitalitas bahasa ke vitalitas sastra mengharuskan indikator-indikator tersebut dimodifikasi supaya kompatibel dengan tradisi lisan. untuk poin 1 mengenai transmisi bahasa akan disesuaikan 
menjadi transmisi sastra antargenerasi yang berkenaan dengan pewarisan sastra lisan Sekujang dari generasi yang lebih tua ke generasi selanjutnya. Poin ini bagi tradisi lisan merupakan unsur paling penting berkenaan dengan keberlangsungannya. Oleh karena itu, pembahasan dengan didasarkan pada teori transmisi Albert B. Lord yang akan dibahas secara lebih lengkap pada subbab 1.2. indikator ini akan mendapat porsi khusus.

Sebaliknya, indikator 2 dan 3 tidak menjadi unsur yang penting karena penutur sastra lisan umumnya individu-individu tertentu yang diberi tanggung jawab terhadap satsra lisan tersebut. Modifikasi yang akan dilakukan pada indikator ini adalah mengganti kedua indikator tersebut dengan seberapa luas tradisi ini dikenal masyarakat. Modifikasi ini dilandaskan pada peran sastra lisan sebagai proyeksi sosial bagi masyarakatnya (Finnegan, 1992:31, Danandjaja, 2015: ).

Indikator 4 dan 5 mengenai kecenderungan dalam ranah pemakaian serta daya tanggap terhadap ranah baru dan media akan lebih tepat jika diganti dengan fungsi sastra lisan bagi masyarakat yang dapat disandarkan pada teori Finnegan. Pada bagian ini juga akan disorot pergeseran makna/peran sastra lisan ini dalam struktur sosial masyarakat Talang Benuang dan persaingannya dengan media/teknologi mutakhir. Penggantian beberapa peralatan dengan barang-barang modern dan efeknya bagi tradisi lisan ini juga akan dibahas pada bagian ini.

Indikator 6,7, dan 9 membahas daya dukungan eksternal terhadap kelestarian tradisi lisan seperti dukungan pemerintah daerah dan akademisi. Bagian ini lebih bersifat evaluasi terhadap aturan dan kebijakan yang sudah ada berkenaan dengan perlindungan sastra oleh pemangku kepentingan. Khusus indikator 9 merupakan hasil penelusuran Pustaka terhadap penelitian dengan objek penelitian Sekujang. Sementara poin 8 berkenaan dengan sikap masyarakat pendukung sastra terhadap tradisi lisan Sekujang.

Penyesuaian tersebut dalam kajian yang dilakukan Badan Bahasa (2017:12) menghasilkan 11 indikator vitalitas tradisi lisan yaitu (1) penutur/seniman tradisi lisan dalam sastra lisan, (2) kontak budaya, (3) penguasaan masyarakat dan sistem pewarisannya, (4) peranan dan ranah penggunaan atau pertunjukan sastra lisan tersebut, (5) kepemilikan masyarakat sebagai sebuah komunitas, (6) sikap masyarakat, (7) perhatian pemangku kepentingan, (8) pendokumentasian yang sudah dilakukan, (9) upaya yang sudah dilakukan, (10) alihwahana, (11) pengayoman pemerintah dan masyarakat. Sebelas indikator tersebut disiapkan sebagai dasar penyusunan penelitian yang bersifat kuantitatif. Masalahnya dalam kasus tradisi lisan, data yang bersifat kuantitatif tidak dapat menggali secara mendalam faktor-faktor dominan yang mendorong suatu tradisi lisan menuju kepunahannya. Pada penelitian ini indikator rumusan badan bahasa tersebut akan disederhanakan dengan pemberian fokus pada beberapa poin utama yang menjadi faktor inti kepunahan sastra lisan melalui pembahasan yang bersifat kualitatif. Oleh karena itu penelitian ini akan menggunakan metode campur (mix method) yang akan dijelaskan dengan dasar sebelas indikator di atas. 


\section{METODE}

Metode yang akan digunakan dalam penelitian ini adalah metode campur (mix method). Dalam penelitian ini, metode campur dioperasikan melalui pengumpulan data kuantitatif dari kuesioner yang diperdalam dengan pengumpulan data kuantitatif melalui metode wawancara. Cara ini diharapkan bisa mengatasi data yang kering akibat pengumpulan data yang terlalu bertumpu pada penilaian angka terhadap indikator.

Informan atau narasumber dari utama dari kegiatan ini adalah tetuo/dukun Sekujang untuk wawancara mengenai tradisi Sekujang dan narasumber dari bidang Kebudayaan Dinas Pendidikan dan Kebudayaan Kabupaten Seluma untuk narasumber mengenai kebijakan dan status tradisi lisan tersebut. Selain itu disebarkan kuesioner sejumlah masyarakat desa Talang Benuang yang dijadikan sampel sebagai responden.

Jumlah sampel ditentukan setelah dilakukan survey lebih dahulu ke Kabupaten Seluma. Jumlah sampel ditentukan dengan teknik sampel acak bertujuan (purposive random sampling) dimana responden yang dipilih secara sengaja melalui pertimbangan keterwakilan populasi oleh sampel tersebut. sampel yang digunakan dalam penelitian ini berjumlah 50 orang. Data dari delapan indikator dikumpulkan melalui kuesioner dan diperdalam melalui teknik wawancara terbuka dan penelusuran pustaka.

Analisis data kualitatif melalui wawancara diolah dengan menggunakan model analisis yang terdiri dari tiga kegiatan utama yang berkaitan satu sama lain, yaitu reduksi data, pengelompokkan dan penyajian data, dan penarikan simpulan. Sementara data kuantitatif dianalisis dengan menghitung frekuensi dan persentase masing-masing item dan pernyataan yang merupakan bagian indikator pengujian vitalitas sastra.

Vitalitas berdasarkan indikator kuantitatif ini diketahui dengan menghubungkan semua variabel indikator dengan subindeks indikator, kemudian digambarkan dalam diagram laba-laba untuk mendapat gambaran bobot subindeks indikator dalam bentuk grafik dua dimensi. Gambaran dalam grafik itu kemudian diinterpretasikan sesuai dengan kriteria vitalitas sastra seperti dalam tabel berikut (Badan Bahasa, 2017: 14).

Tabel Kriteria Vitalitas Sastra

\begin{tabular}{|c|l|c|c|}
\hline \multirow{2}{*}{ No. } & \multicolumn{1}{|c|}{ Kriteria Vitalitas Sastra } & \multicolumn{2}{|c|}{$\begin{array}{c}\text { Angka dan Garis Indeks } \\
\text { Diagram Jaring Laba-laba }\end{array}$} \\
\cline { 3 - 4 } & \multicolumn{1}{|c|}{$\begin{array}{c}\text { Angka Indeks } \\
\text { Garis Indeks }\end{array}$} \\
\hline 1 & $\begin{array}{l}\text { Punah; tidak ada penutur dan } \\
\text { masyarakat pendukungnya. }\end{array}$ & 0 & 0 \\
\hline 2 & $\begin{array}{l}\text { Kritis/ sangat terancam (saverely } \\
\text { endangered): }\end{array}$ & $0,0-0,20$ & $1-2$ \\
\hline 3 & Terancam (endangered) & $0,21-040$ & $2-3$ \\
\hline 4 & Mengalami kemunduran (eroding) & $0,41-0,60$ & $3-4$ \\
\hline 5 & $\begin{array}{l}\text { Stabil tapi mulai terancam punah } \\
\text { (stable, but threatened) }\end{array}$ & $0,61-0,80$ & $4-5$ \\
\hline 6 & Aman (safe) & $0,81-1$ & $5-6$ \\
\hline
\end{tabular}




\section{PEMBAHASAN}

\section{Sekilas Tradisi Lisan Sekujang di Desa Talang Benuang, Kabupaten Seluma}

Sekujang adalah ritual tahunan masyarakat Serawai yang diadakan pada rayo pertamo. Sebenarnya ada kesalahpahaman bahwa hari lebaran pertama berlangsung hingga malam, padahal malam pelaksanaan telah jatuh pada tanggal 2 syawal. Tradisi Sekujang dilakukan sebagai upaya mendoakan jemo putus (Wibowo, 2014:42). Jemo putus adalah istilah orang yang telah putus silsilah keluarganya karena tidak memiliki keturunan. Namun Wibowo (2014:42) menjelaskan bahwa sekarang defenisi jemo putus semakin meluas, meski masih berkaitan dengan ketiadaan keturunan. Orang yang tidak memiliki keturunan saat ini termasuk ibu yang meninggal melahirkan, waria, orang yang mati bujang, anak-anak yang meninggal, bahkan orang yang mati tanpa diketahui keberadaannya/tidak memiliki kubur (misalnya mati di laut, di tengah hutan lebat, mati hanyut dan tidak ditemukan mayatnya, mati karena jatuh ke dalam jurang). Akibat pengaruh islam, Jemo putus dimaknai oleh penduduk setemapat sebagai orang-orang yang tidak mendapatkan doa dari keturunannya pada hari Idul Fitri. Hal ini berkaitan dengan tradisi ziarah kubur pada masyarakat melayu untuk mendoakan leluhur mereka. Jemo Putus tidak memiliki keturunan yang mendoakan atau tidak memiliki untuk diziarahi.

Sekujang pada dasarnya adalah sebutan untuk arwah-arwah yang kembali pada lebatan kedua karena tidak mendapat doa dari keturunan tersebut. Roh-roh ini dipercaya akan mencegah melekatnya bunga buah-buahan (mencegah proses pembuahan tumbuh-tumbuhan) seperti durian, manggis, rambutan, petai, dan lainlain jika tidak didoakan. Bunga-bunga tersebut akan gugur dan buah-buahan pun tidak bisa dipanen. Tradisi ini merupakan wujud doa masyarakat agar arwaharwah tersebut tenang dan tidak mengganggu tanaman mereka (Wibowo, 2014: 42).

Masyarakat setempat percaya bahwa arwah jemo putus yang menjadi Sekujang pertama kali adalah arwah Pak Pandir. Dikisahkan bahwa Pak kisah lengkapnya dapat disimak pada deskripsi berikut:

\footnotetext{
Pandir dan istrinya merupakan orang miskin yang tidak memiliki rumah. Namun ia ingin merayakan hari raya idul fitri seperti masyarakat lainnya. Karenanya pasangan tersebut mendatangi setiap rumah di desanya untuk meminta sisa tumbukan padi di antan untuk membuat kue. Setelah setiap rumah telah didatangi dan kue-kue telah terkumpul, Pak Pandir bingung harus dibawa kemana kue tersebut karena ia tidak memiliki rumah. Akhirnya, ia membawa kue yang ia peroleh ke surau untuk didoakan dan dimakan di sana.
}

Tindak-tanduk Pak Pandir dalam cerita tersebut menjadi urut-urutan pelaksanaan tradisi Sekujang. Sebagai symbol arwah Sekujang yang kembali, para peserta tradisi Sekujang diberbalut kostum tertentu yang disebut Sekura. Pada mulanya kostum Sekura hanya terbuat dari ijuk untuk arwah Pak Pandir dan kerisiak (pelepah pisang kering) untuk istrinya. Sekura menggunakan topeng yang disebut Sekura Dayi yang dapat terbuat dari upih pinang atau kayu. Menurut tetuo sekujang jumlah Sekura ini pada awalnya hanya enam pasang. Dewasa ini, sejalan dengan berkembangnya makna jemo putus, jumlah Sekura bertambah dengan 
bentuk yang lebih variatif. Untuk mewakili semua arwah yang tergolong jemo putus sudah ada Sekura yang berbentuk ibu hamil, pocong anak-anak, dan waria.

Para Sekuro ini akan berkeliling kampung untuk meminta kue ke rumahrumah penduduk. Sebelum berkeliling kampung, Tetuo Sekujang akan meminta izin dahulu kepada Puyang Mulo Jadi untuk melepaskan para Sekura. Lalu untuk menghindarkan bahaya, digunakan air tepung setawar sebagai pelindung mereka dari rasa gerah, gatal karena ijuk, dan bahaya seperti tersulut api. Setelah itu barulah mereka dilepas dengan tari nelas.

Para Sekuro akan menyanyikan Ratapan Sekujang sepanjang perjalan mereka. Ratapan Sekujang berupa lima hingga tujuh bait pantun, tergantung dengan respon pemilik rumah yang mereka datangi. Tiga teks pertama merupakan pantun pembuka Ratapan Sekujang. Berikut teks ratapan sekujang yang dikutip dari Wibowo (2014: 43)

\author{
Jang sekujang anai-anai bawah batang \\ Betukup daun buluah \\ Anak muanai banyak datang \\ Ado seratus tigo puluah \\ Ke Paliak bukan ke Lintang \\ Tengah jalan ke Tanggo raso \\ Mako kami sekujang \\ La rerayo bulan puaso \\ Menebang muaro santang \\ tepaut timbul tenggelam \\ Kalo kami lambat datang \\ Dusun jauah padam bekelam
}

Jika setelah dibacakan pantun ini tuan rumah memberikan kue, maka para Sekuro membacakan bait berikut:

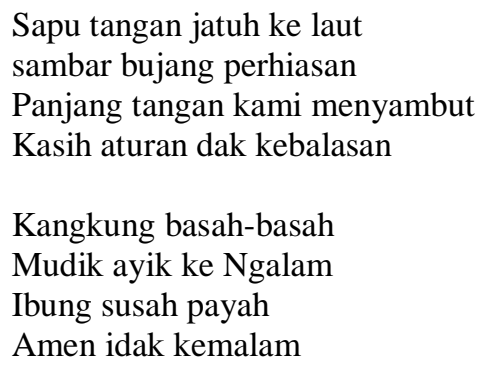

Namun jika tuan respon tuan rumah lambat maka dari tiga bait pembuka para sekuro atau pembaca ratap sekujang menyanyikan bait ini:

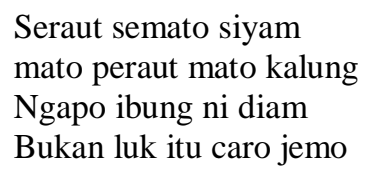

Jika belum juga dibukakan pintu maka diiringi dengan bait berikut; Besak iluak pandak 
Iluak gadis Talang Aji

Iluak endak iluak adak

Iluak ado suko dinanti

Keluang bada kelambit

Besarang di daun geduak

Puyang bepenyakit

digergak langsung tiduak

Jika tidak juga mendapat respon maka Sekuro meninggalkan rumah tersebut dengan menyanyikan bait berikut:

Srindit mandi pagi

Duo sekawan terkuku

Alangke kerit ghuma ini

munyikan cucur balik tungku

Ratapan Sekujang terdiri dari dua bagian, yaitu bagian pendahuluan sebanyak tiga bait dan bagian ucapan terima kasih atau sindiran. Tiga bait pendahuluan ini bertujuan menjelaskan kedatangan mereka (anak muanai banyak datang), menginformasikan bahwa waktu sekujang telah tiba (la rerayo bulan puaso), dan alasan kenapa mereka datang (dusun jauh padam bekelam).

Bagian kedua jumlahnya sangat tergantung pada respon tuan rumah. Jika langsung diberi maka dibacakan satu bait pantun terima kasih. Namun jika tidak langsung mendapat respon, maka ada tiga bait pantun sindiran yang dinyanyikan yang terdiri dari sindiran halus (bukan luak itu caro jemo), lalu kasar (iluak ado suko dinanti dan digergak langsung tiduak), dan sangat kasar (alangke kerit ghuma ini, munyikan lemang di balik tungku).

Sebagai balasan kue yang diberikan, pihak pemberi kue dapat meminta Sekura untuk meminta sesuatu, seperti bernyanyi, berpantun, bertakbir, menari, bahkan meminta kesembuhan dan keberuntungan. Sekura harus menuruti perintah sang tuan rumah. Proses ritual ini berlangsung hingga tengah malam. Kue-kue yang dikumpulkan tersebut dibawa ke masjid untuk kemudian didoakan oleh imam dan perangkat desa.

\section{Vitalitas Sastra Lisan Sekujang di Kabupaten Seluma}

Dari 50 kuesioner yang disebar, hanya 49 kuesioner yang kembali. Dari jumlah tersebut terdapat 3 kuesioner yang tidak dapat digunakan, sehingga secara keseluruhan terdapat 46 kuesioner yang digunakan sebagai sumber data. Respon masyarakat pemilik tradisi Sekujang berdasarkan 46 kuesioner tersebut dapat dilihat dalam diagram laba-laba berikut. 


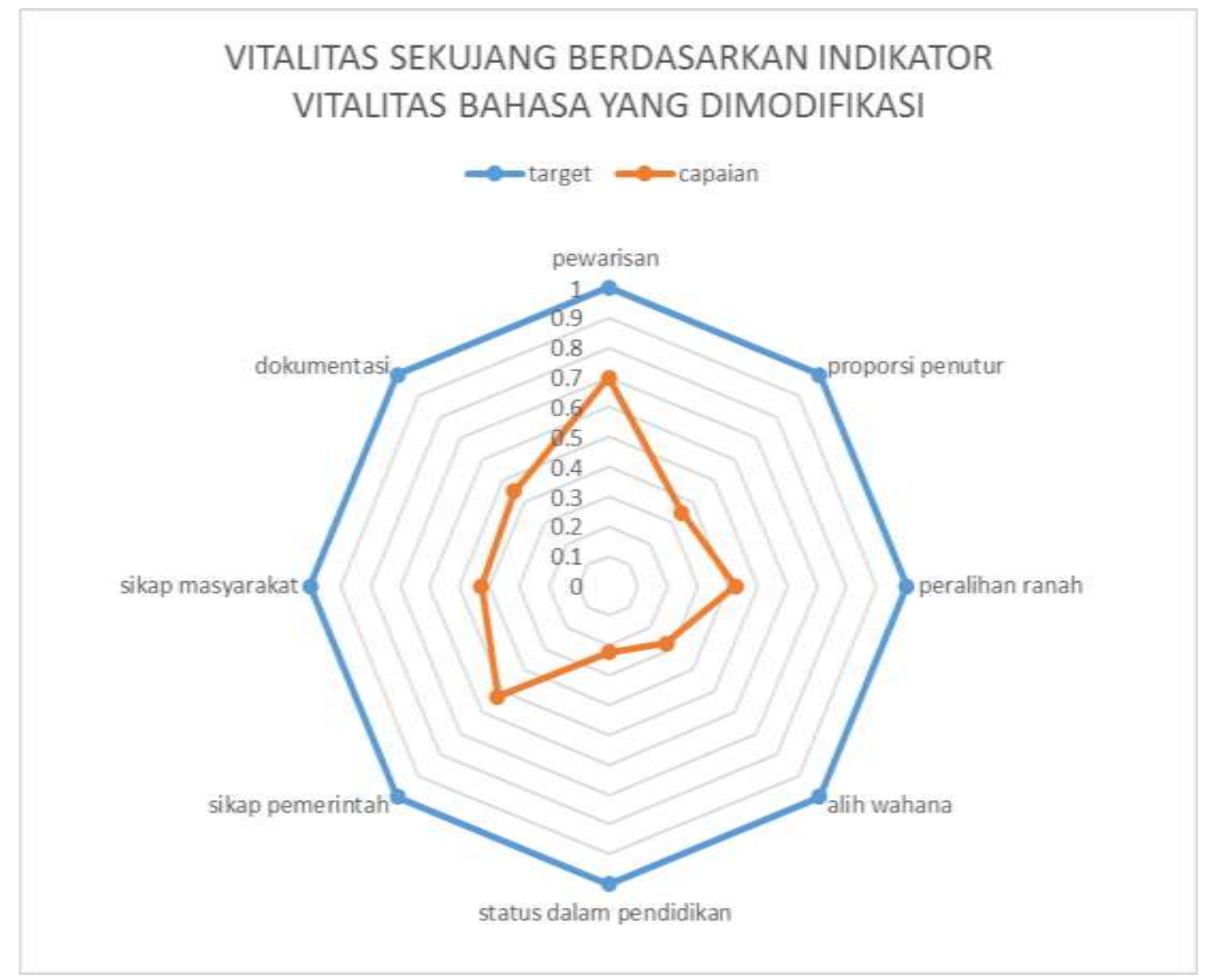

Penelitian ini menghasilkan kesimpulan bahwa vitalitas sastra lisan Sekujang berada pada tahap mengalami kemunduran (eroding) dengan skor 0,42. Indikator pewarisan di kalangan generasi muda mendapat skor indeks 0,70 yang dapat dimaknai bahwa sekujang masih ditampilkan oleh kaum muda dan anakanak tetapi jumlah penuturnya sedikit dan cenderung mengalami penurunan. Saat ini tetuo Sekujang sebagai otoritas pelaksana berjumlah kurang dari sepuluh orang, bahkan mungkin hanya tinggal Mat Zakir saja. Dari wawancara diketahui juga bahwa ketiadaan lembaga resmi seperti sanggar membuat transmisi Sekujang mengalami hambatan untuk sampai ke generasi yang lebih muda. Pewarisan terstruktur hanya terjadi dalam kepanitiaan Sekujang yang dibentuk pada bulan Ramadhan setiap tahunnya. Pewarisan dengan cara ini tidak berkelanjutan dan cenderung membuat pengetahuan mengenai sastra lisan Sekujang diterima secara sepotong-sepotong. Secara sosial, tranmisi mampu mencapai generasi muda karena pelaksanaan Sekujang masih dilakukan secara rutin setiap tahun. Akan tetapi mekanisme transmisi ini tidak menghasilkan penutur karena proses transmisi yang tidak disertai dengan kewenangan untuk melakukan tradisi ini. pengetahuan tentang sekujang dalam transmisi ini hanya berwujud pengetahuan.

Proporsi penutur Sekujang dengan populasi penduduk mendapat skor ratarata 0,35 yang dimaknai minoritas orang bisa menampilkan Sekujang. Hasil ini terbilang mengejutkan karena penampil Sekujang tidak dibatasi. Setiap orang bisa 
menjadi Sekura selama mendaftarkan diri pada kepanitiaan. Konfirmasi melalui wawancara menunjukkan bahwa persepsi masyarakat tentang penampil Sekujang terbatas pada tetuo sekujang dan panitia sekujang saja. Para penampil lain dinilai hanya 'ikut-ikutan.' Hasil ini dapat dikatakan agak menjebak, karena mekanisme transmisi sosial memungkinkan setiap masyarakat di desa Talang Benuang sebagai penutur, namun pelembagaan yang berkaitan dengan kewenangan pelaksanaan menimbulkan anggapan bahwa penutur sekujang hanya terbatas pada sebagian orang saja. Hasil ini problematis, namun tetap dianggap valid menimbang ketiadaan mekanisme transmisi formal tradisi lisan ini.

Untuk peralihan ranah Sekujang skor indeks yang didapat adalah 0,43 karena meski dapat ditampilkan di setiap tempat, Sekujang dalam konteks ritualnya hanya dapat ditampilkan pada hari lebaran pertama saja. Meski demikian pada masa sekarang sekujang diketahui mulai dipentaskan di luar momen tersebut seperti diikutsertakan pada festival Tabot dan Pekan Sastra 2016. Dengan berkembangnya teknologi informasi. Sekujang saat ini tidak dianggap bersaing dengan hiburan modern, meski pesta perkawinan sudah lazim menggunakan organ tunggal. Masyarakat desa Talang Benuang menganggap bahwa ranah keduanya berbeda. Keberadaan Sekujang dalam ranah ritual pada masyarakat Talang Benuang inilah salah satu faktor terpenting yang menjaga vitalitas sastra lisan ini tetap tinggi dan tidak tergeser pada bentuk hiburan modern.

Sekujang dianggap tidak cukup adaptif terhadap pengalihan wahana karena hanya mendapat skor indeks 0,27. Hal ini berarti Sekujang hanya dapat ditampilkan pada beberapa tempat dan acara yang terbatas saja serta hanya dapat dialihkan pada beberapa media baru. Menilik karakteristik Sekujang yang terbuka, alihwahana ini sesungguhnya memiliki potensi yang luas. Hasil yang tergolong rendah ini saat ,dilakukan wawancara terbatas, disebabkan oleh ketidaktahuan masyarakat mengenai alihwahana. Hal ini terjadi karena tidak ada contoh alihwahana yang dilakukan terhadap Sekujang.

Untuk statusnya dalam pembelajaran di sekolah Sekujang mendapat skor 0,22. Meski telah mendapat perhatian dan promosi dari media baik cetak maupun eletronik serta sedang ditulis beberapa buku mengenainya, sastra lisan Sekujang belum menjadi bagian dari kurikulum sekolah. Masyarakat mengetahui terdapat beberapa karya ilmiah tentang sekujang yang ditulis baik oleh mahasiswa maupun peneliti, namun tidak pernah mengaksesnya. Jika dikaitkan dengan kualitas dokumentasi, memang ditemukan bahwa dokumentasi sastra lisan yang berkualitas sangat minim, bahkan tidak ada dokumentasi berbentuk buku. Kerumpangan ini menjadi penyebab utama tidak dapat diintegrasikannnya Sekujang ke dalam kurikulum pendidikan muatan lokal karena ketiadaan makalah akademis (academic papers) sebagai landasan.

Sikap pemerintah terhadap Sekujang mendapat skor indeks 0,52. Belum ada kebijakan tertulis pemerintah yang melindungi sastra minoritas seperti Sekujang dan dorongan untuk menggabungkan Sekujang dengan sastra populer menjadi ancaman tersendiri bagi Sekujang. Wawancara dengan pihak Dinas Pendidikan punmenemukan bahwa terdapat kekosongan aturan yang menajdi payung bagi kelestarian dan/atau pengembangan sastra lisan. bahkan ditemukan dalam dokumen Pokok Pikiran Kebudayaan Daerah Kabupaten Seluma (2018: 27), 
Sekujang digolongkan sebagai salah satu jenis tarian daerah. Pandangan ini menafikan unsur-unsur ritual dan sastra lisan dalam pertunjukan Sekujang dan hanya melihat kulit luarnya saja, padahal aspek ritual dan mitos menjadi bagian paling penting dalam menjaga denyut vitalitas sastra lisan Sekujang.

Hasil yang kontradiktif dihasilkan dari indikator sikap masyarakat terhadap Sekujang mendapat skor 0,42. Hasil ini dikatakan demikian karena terdapat perbedaan hasil saat dilakukan konfirmasi melalui wawancara. Mayoritas responden yang kembali diwawancarai menunjukkan sikap positif yang tinggi terhadap Sekujang. Hasil tersebut lebih disebebkan kendala teknis dalam memahami pernyataan-pernyataan dalam kuesioner. Kepala desa yang diwawancarai dengan sangat yakin mengungkapkan bahwa hanya terdapat dua kepala keluarga yang menolak pelaksanaan Sekujang karena dianggap sebagai tindakan syirik. Tolak ukur utama masyarakat adalah selalu ramainya perhelatan Sekujang dan pengumpulan dana swadaya untuk terlaksananya kegiatan ini secara rutin merupakan cerminan yang dianggap sebagai sikap positif tersebut.

Skor Indeks yang didapat untuk kualitas dokumentasi dari kuesioner adalah 0,45 . Capaian ini bermakna masyarakat tidak mengetahui secara pasti adanya dokumentasi tradisi lisan Sekujang dalam bentuk apapun. Akan tetapi penelusuran pustaka sejauh ini menemukan bahwa dokumentasi Sekujang masih terpisahpisah dengan rekaman audio dan video yang kurang memadai. Tiga karya ilmiah dimiliki oleh Kantor Bahasa Bengkulu dan tiga lainnya terdapat di dua Univeristas yaitu dua di IAIN Bengkulu dan satu di Universitas Bengkulu. Potongan rekaman video dengan kualitas rendah dimiliki oleh masyarakat, hanya ada satu rekaman yang dimiliki oleh peneliti itupun tanpa da penjelasan sama sekali di dalamnya.

\section{Refleksi Penelitian Vitalitas Sekujang}

Terdapat dua sisi yang dapat direfleksikan dari penelitian vitalitas Sekujang ini, yaitu refleksi teoritis dan refleksi revitalitasi sastra. Refleksi yang berkenaan dengan vitalitas sastra lisan sekujang disimpulkan dari pengukuran vitalitas menggunakan indikator vitalitas bahasa menemukan dua titik paling lemah dari Sekujang. Kelemahan pertama terletak pada alih wahana dan status Sekujang dalam pendidikan. Kedua hal tersebut berkait kelindan dengan kuantitas dan kualitas dokumentasi sastra Lisan Sekujang yang masih terbilang minim. Oleh karena itu langkah awal yang dapat dilakukan dalam melestarikan tradisi lisan Sekujang adalah mengalihwahanakannya ke bentuk buku atau video. Setelah kedua hal tersebut dilakukan maka perlu dilakukan dengar pendapat dengan pemangku kepentingan di Seluma sebagai langkah memperkenalkan dan mengusahakan tradisi lisan ini masuk ke dalam kurikulum pendidikan sekolah.

Sikap positif masyarakat dapat dikategorikan tinggi, sehingga dapat dipandang sebagai modal yang besar bagi keberlangsungan Sekujang. Akan tetapi, tidak adanya ajang untuk terjadinya tranmisi secara formal, seperti sanggar, merupakan salah satu bentuk sumbatan transmisi yang harus dibenahi. Hanya melalui skema transmisi terstruktur semacam sanggar, Sekujang dapat diwariskan secara utuh. Untuk mengatasi hal ini perlu dilakukan stimulus terhadap aparat 
desa dan pelaku budaya Sekujang untuk membentuk lembaga yang lebih tersistem dan berbadan hukum demi lebih memastikan posisi Sekujang tetap aman.

Refleksi dari sisi teoritis dilakukan bukan karena hasil penelitian tidak sesuai dengan asumsi awal, akan tetapi terdapat masalah-masalah yang teridentifikasi dalam proses penarikan kesimpulan tersebut. Masalah-masalah tersebut dapat disimak dalam daftar berikut.

1. Dalam menanggapi kuesioner, responden cenderung menyesuaikan dengan harapannya dari pada kondisi objektif Sekujang, sehingga kuesioner dapat dikatakan tidak merefleksikan kondisi riil Sekujang. Hal ini terindikasi dari indikator alihwahana dan sikap masyarakat yang kontradiktif.

2. Proporsi antara penutur dan masyarakat menjadi variabel yang paling menjebak. Hal ini terjadi karena secara teknis sampel hanya diambil dari desa Talang Benuang saja dimana tradisi ini dilestarikan. Disadari kemudian bahwa faktor ini tidak berpengaruh banyak dalam keberlangsungan sastra lisan Sekujang karena otoritas dan pengetahuannya hanya dimiliki oleh tetuo Sekujang. Dari cerita masyarakat setempat, sastra lisan ini punah di Sukaraja karena meninggalnya tetuo sekujang meski masih ada masyarakat yang mengatahui proses pelaksanaannya.

3. Kecenderungan masyarakat untuk menganggap pemerintah sebagai pihak Pemerintah Kabupaten sehingga terdapat ketidaksesuaian antara lingkup penelitian dengan dimensi pemerintah dalam benak masyarakat menghasilkan data yang kurang presisi.

4. Dokumentasi berupa hasil-hasil penelitian tidak dapat diakses oleh penduduk yang sebagian besar tidak melanjutkan ke pendidikan tinggi. Hasil dokumentasi tersebut tidak pula dimiliki oleh pihak desa. Sehingga respon mereka terhadap kualitas dokumentasi patut diragukan.

Dalam prosesnya, permasalahan tersebut berusaha dipecahkan dengan tiga solusi untuk menambal kekurangakuratan data hasil penjaringan kuesioner yaitu 1) memperluas DP dengan kriteria desa-desa yang menjadi kandidat DP pernah memiliki sastra lisan Sekujang yang menghasilkan dua DP pilihan yaitu Kelurahan Sukaraja dan Desa Napal Jungur. 2) menggunakan pendekatan wawancara dan observasi. 3) studi pustaka dan dokumentasi dilakukan dengan peneliti sebagai instrumen utamanya. Solusi ini menyelesaikan masalah perbedaan asumsi mengenai pemerintah dan penelusuran dokumentasi. Namun membuka masalah baru berkaitan dengan sikap positif dan proporsi jumlah penduduk.

Di Sukaraja, sekujang baru digalakkan kembali dua tahun belakangan. Penggiatnya masih bertalian darah dengan tetuo sekujang di Talang Benuang. Namun berdasarkan pengakuan masyarakat setempat akar Sekujang di daerah Sukaraja bukan berasal dari Talang Benuang karena sebelumnya Sukaraja memiliki tetuo Sekujang sendiri yang tidak mewariskan ilmunya. Sambutan masyarakat terhadap revitalisasi secara swadaya Sekujang di Sukaraja sangat baik. Hal ini menandakan bahwa sikap positif terhadap sastra lisan ini tinggi. Hanya saja saat ini tetap belum bisa menjawab masalah sumbatan pewarisan Sekujang 
yang menjadi penyebab tradisi lisan ini mati suri di masa sebelumnya. Namun patut disyukuri bahwa ada mekanisme yang terbuka terhadap pergantian tetuo Sekujang, dimana masyarakat dari desa lain pun dapat menduduki posisi tersebut jika memang memiliki kemampuan dan kelayakan.

Sementara di desa Napal Jungur, sastra lisan Sekujang tinggal berupa mitos mengenai roh nenek moyang yang kembali pada hari rayo keduo. Ekspresi tradisinya dapat dikatakan punah sama sekali. Mayoritas penduduk bahkan tidak mengetahui pada zaman dahulu desa mereka juga menyelenggarakan tradisi Sekujang. Akan tetapi hasil wawancara menunjukkan sikap positif yang tinggi terhadap keberlangsungan sastra lisan ini. Rata-rata masyarakat setuju jika tradisi ini dihidupkan lagi. Akan tetapi temuan penting dari perluasan DP ini justru mengarah pada evaluasi terhadap kesesuaian teori vitalitas bahasa untuk mengukur vitalitas sastra yang akan dijelaskan di bawah.

Masalah-masalah yang bersifat teknis di atas, dalam penelusuran lebih jauh, berakar pada kesalahan asumsi dasar yang menganggap terdapat keterikatan erat antara sastra dan bahasa, sehingga punahnya bahasa selalu diikuti kepunahan sastra. Asumsi tersebut pun tidak terkonfirmasi di lapangan. Temuan lapangan menunjukkan bahwa banyak contoh kepunahan bahasa yang tidak diikuti oleh kepunahan sastra. Kesimpulan ini dirumuskan karena mantra dalam sastra lisan Sekujang dapat menggunakan bahasa Rejang yang bukan bahasa asli masyarakat Serawai Talang Benuang. Fakta ini mengarah pada penelusuran mantra-mantra dalam masyarakat Serawai dan masyarakat Bengkulu secara umum. Menariknya hampir dalam semua mantra meski bahasa yang digunakan masih merupakan bahasa Serawai namun baik secara struktur maupun diksinya bukanlah bahasa yang diguankan oleh masyarakat. Bukti yang lebih populer dapat ditemukan dalam Upacara Tabut pada etnis Melayu Bengkulu. Prosesi ritual upacara tersebut menggunakan bahasa Sipai yang sama sekali berbeda dengan bahasa Melayu Bengkulu. Ada kecenderungan bahwa bahwa kepunahan bahasa tidak selalu diikuti oleh kepunahan sastra.

Penyebab lain yang menyebabkan teori vitalitas bahasa lisan kurang kompatibel dalam pemetaan vitalitas sastra adalah karakteristik sastra lisan yang terus mengalami reproduksi dan rekreasi dalam penyebaran dan pewarisannya. Dalam asumsi vitalitas bahasa, terdapat bahasa purba yang menjadi tolak ukur keaslian suatu bahasa yang turut menentukan vitalitasnya. Bentuk purba ini dapat direkonstruksi secara struktural dan dipertanggungjawabkan hasilnya secara ilmiah. Sementara karena sifatnya yang komunal, bentuk asli suatu sastra lisan tidak mungkin ditentukan. Dalam penyebarannya baik lintas masa maupun lintas suku, proses reproduksi dan rekreasi terhadap sastra tersebut berlangsung secara berkelanjutan. Dengan demikian, setiap teks dapat dianggap sebagai teks asli. Setiap masyarakat dapat menganggap sastra lisan milik mereka sebagai bentuk paling murni sebagai konsekuensi proses tersebut. Dalam masyarakat Bengkulu, hal ini terlihat paling jelas dalam genre sastra lisan andai-andai dan nandai serta guritan atau geguritan. Sebarannya sangat luas dan lintasetnis dengan masingmasing etnis mendaku bentuk sastra mereka yang paling tua. Rekonstruksi yang menetapkan satu bentuk sastra lisan milik etnis tertentu sebagai pakem cenderung menimbulkan friksi antaretnis. Dalam lingkup Indonesia kasus serupa dengan 
implikasi yang lebih serius dapat ditemukan dalam sastra Kabhanti antara Suku Muna dan Palu.

Pengukuran vitalitas sastra lisan menggunakan teori vitalitas sastra sebagai indikator tidak dapat menunjukkan kondisi riil sastra lisan yang menjadi objek, bahkan cenderung menghasilkan data yang tidak akurat. Agaknya dalam upaya melestraikan sastra lisan, harus dicari metode baru yang lebih cocok dengan karakteristik sastra lisan itu sendiri. Pilihan kedua, jika ingin tetap mempertahankan teori vitalitas bahasa sebagai dasar perlu dicari landasan yang lebih kuat serta modifikasi yang dapat mengakomodasi karakter sastra lisan atau dengan kata lain sebuah modifikasi menyeluruh. Bagaimana metode baru tersebut dirumuskan tidak dapat dilakukan sendiri, melainkan harus didiskusikan bersama antarpeneliti. Revitalisasi tradisi lisan membutuhkan metode yang dapat menjembatani masalah waktu pelaksanaan yang panjang dan data yang hanya menyentuh permukaan, sehingga vialitas suatu sastra lisan dapat ditentukan dalam waktu yang ringkas dengan data yang memadai.

\section{PENUTUP}

Hasil penelitian ini menunjukkan bahwa vitalitas Sekujang berada pada derajat mengalami kemunduran (eroding) dengan skor 0,42 dari skala 1,00. Hasil ini diperoleh dengan rincian: 1) indikator pewarisan di kalangan generasi muda mendapat skor indeks 0,$70 ; 2$ ) proporsi penutur dengan dengan populasi penduduk mendapat skor indeks 0,$35 ; 3$ ) peralihan ranah mendapat skor indeks $0,43 ; 4)$ alih wahana mendapat skor indeks 0,$27 ; 5)$ status pembelajaran di sekolah mendapat skor indeks 0,$22 ; 6$ ) sikap pemerintah mendapat skor indeks 0,$52 ; 7$ ) sikap masyarakat mendapat skor indeks 0,$52 ; 8)$ jumlah dan kualitas dokumentasi mendapat skor indeks 0,45 . Hasil tersebut dirumuskan dengan catatan pada dua indikator dengan data yang kontradiktif yaitu indikator 2 dan 7.

Berdasarkan hasil refleksi terhadap penelitian vitalitas Sekujang dengan menggunakan indikator vitalitas bahasa dirusmuskan saran-saran sebagai berikut.

1. Dua langkah yang harus segera dilakukan untuk menjaga tingkat vitalitas Sekujang adalah mengalihwahanakannya atau mendokumentasikannya dan membentuk sanggar yang dapat menjadi ajang terjadinya transmisi lintas generasi.

2. Pengukuran vitalitas sastra lisan menggunakan teori vitalitas sastra sebagai indikator tidak dapat menunjukkan kondisi riil sastra lisan yang menjadi objek, bahkan cenderung menghasilkan data yang tidak akurat. Agaknya dalam upaya melestraikan sastra lisan, harus dicari metode baru yang lebih cocok dengan karakteristik sastra lisan itu sendiri. Pilihan kedua, jika ingin tetap mempertahankan teori vitalitas bahasa sebagai dasar perlu dicari landasan yang lebih kuat serta modifikasi yang dapat mengakomodasi karakter sastra lisan atau dengan kata lain sebuah modifikasi menyeluruh. Bagaimana metode baru tersebut dirumuskan tidak dapat dilakukan sendiri, melainkan harus didiskusikan bersama antarpeneliti. Revitalisasi tradisi lisan membutuhkan metode yang dapat menjembatani masalah waktu pelaksanaan yang panjang dan data yang hanya menyentuh permukaan, sehingga vialitas 
suatu sastra lisan dapat ditentukan dalam waktu yang ringkas dengan data yang memadai

\section{DAFTAR PUSTAKA}

Danandjaja, James. (2015). "Pendekatan Folklor dalam Penelitian Bahan-Bahan Tradisi Lisan" dalam Pudentia (editor). Metodologi Kajian Tradisi Lisan: Edisi Revisi. Jakarta: Asosiasi Tradisi Lisan.

Dinas Pendidikan dan Kebudayaan Daerah Kabupaten Seluma. (2018). Pokok Pikiran Kebudayaan Daerah Kabupaten Seluma Tahun 2018. Seluma: Dinas Pendidikan dan Kebudayaan Seluma.

Finnegan, Ruth. (1992). Oral Tradition and Verbal Arts. London: Routledge.

Gunarwan, Asim. (2011). Pembalikan Pergeseran Bahasa Daerah untuk Memperkukuh Budaya Bangsa dalam buku Pemberdayaan Bahasa Indonesia Memperkukuh Budaya Bangsa dalam Era Globalisasi: Risalah Kongres Bahasa Indonesia VIII, Badan Pengembangan dan Pembinaan Bahasa.

Harimansyah, Ganjar, dkk. (2017). Kajian Vitalitas Sastra Lisan Ternate. Jakarta: Badan Pengembangan dan Pembinaan Bahasa.

Lord, Albert B. (1971). The Singer of Tales. New York: Harvard University Press.

UNESCO. tanpa tahun. Language Rights of Linguistic Minorities: A Practical Guide of Implementation.

Wibowo, Sarwo Ferdi. (2014). Sekujang di Ambang Hilang: Usaha Pelestarian Tradisi Lisan Melalui Film Dokumenter dalam Jurnal Jentera vol. 4, No. 1 Juli 2014. Jakarta: Badan Bahasa. 